
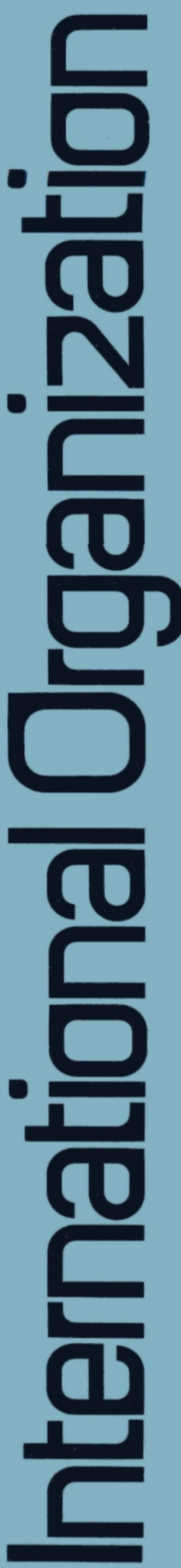
itited at Stanford University. and Published bu the Universitu of Wisconsin Press

onsored by the World Peace Foundation, , 


\section{Board of Editors}

Robert O. Keohane, Editor

Ernst B. Haas, Chairman

Richard Bilder

James A. Caporaso

Benjamin J. Cohen

Robert W. Cox

Leon Gordenker

Roger D. Hansen

Rosalyn Higgins

Fred Hirsch

Stanley Hoffmann

Harold K. Jacobson

Peter J. Katzenstein

Stephen D. Krasner

Edward L. Morse

Henry R. Nau

Richard Rosecrance

John Gerard Ruggie

Lawrence Scheinman (on leave)

Eugene B. Skolnikoff

Joan Spero

Susan Strange

Louis T. Wells
International Organization is sponsored by the World Peace Foundation, a nonprofit educational organization. Statements of fact and opinion are made on the responsibility of the authors alone and do not imply the endorsement of the Board of Editors or the Board of Trustees of the World Peace Foundation, nor of the University of Wisconsin-Madison or the University of Wisconsin Press.

\section{Editorial office:}

Mr. Robert O. Keohane, Editor

Center for Research in International Studies Stanford University

Stanford, California 94305

Manuscripts, to be returned, must be accompanied by a self-addressed envelope with sufficient first-class postage. The editors can assume no responsibility for loss or damage of any work submitted. All manuscripts are to be submitted in triplicate, and all footnotes must be placed together at the end of each manuscipt-not at the bottom of each page. Details should conform to those recommended by the University of Chicago's $A$ Manual of Style.

Business office:

All correspondence about advertising, subscriptions, and allied matters should be sent to: Journals Department, University of Wisconsin Press, Box 1379, Madison, Wisconsin 53701. Second Class Permit at Madison, Wisconsin, and additional mailing offices.

\section{Subscription information:}

Libraries and institutions: one year, $\$ 25.00$; individuals: one year, $\$ 12.50$, two years, $\$ 22.00$, three years, $\$ 30.00$, (individuals must prepay). Add $\$ 2.00$ foreign postage.

(C) 1978 by the Regents of the University of Wisconsin System US-ISSN 0020-8183 


\title{
THE GLOBAL POLITICAL ECONOMY OF FOOD
}

\author{
Edited by \\ Raymond F. Hopkins \\ Swarthmore College \\ and \\ Donald J. Puchala
}

Columbia University

SUMMER 1978

Volume 32, Number 3 
International Organization publishes analytical articles, review essays of current literature, notes dealing with problems of theoretical and methodological interest, and comments designed to encourage lively interchanges on issues of wide interest.

International Organization particularly welcomes manuscripts that focus on the development and functioning of international agencies or arrangements, (including regional ones), or on their relationships with the political and economic environments. The journal is also interested in articles on transnational relations and on problems of intergovernmental policy coordination in the absence of international institutions.

The Board of Editors welcomes original critical analyses. It is not interested in mere descriptions or chronological treatments of institutions. Manuscripts should provide fresh interpretations and evaluations of significant developments or trends; they should not repeat material familiar and available elsewhere to specialists in international affairs.

Manuscripts, in order to be considered, should be sent in triplicate to the Editor, Robert Keohane, Center for Research in International Studies, Stanford University, Stanford, CA. 94305. Articles and review essays should not exceed 45 double-spaced typewritten pages $\left(8^{1 / 2} \times 11^{\prime \prime}\right)$. Notes on theory and method and comments should not exceed 2,000 words. The style followed should be consistent with the University of Chicago Manual of Style.

Decisions on publication are made pursuant to independent critical comment by two or more readers. Authors may expect a decision within eight weeks of the Editor's receipt of a manuscript. 


\section{Special Issue:}

THE GLOBAL POLITICAL ECONOMY OF FOOD

\section{Contents}

Preface

\section{SECTION I Overview}

Perspectives on the international relations of food. Raymond $F$. Hopkins and Donald J. Puchala.

\section{SECTION II Food Policies of Important Countries}

United States food policy 1972-1976: reconciling domestic and international objectives. I. M. Destler.

Shifting and sharing adjustment burdens: the role of the industrial food importing nations. Robert L. Paarlberg.

The politics of food scarcities in developing countries. Norman K. Nicholson and John D. Esseks. 
SECTION III Economics, Politics, and the World Food System

Food markets and their regulation. Gary L. Seevers.

World hunger: a structural approach. Cheryl Christensen.

The diplomacy of world food: goals, capabilities, issues and arenas. Henry R. Nau

Institutional dimensions of the malnutrition problem. James E. Austin.

\section{SECTION IV Considerations for Future Policy}

World food institutions: a "liberal" view. D. Gale Johnson.

Toward innovation in the global food regime. Donald J. Puchala and Raymond $F$. Hopkins.

International food organizations: a glossary.

Selected bibliography. 